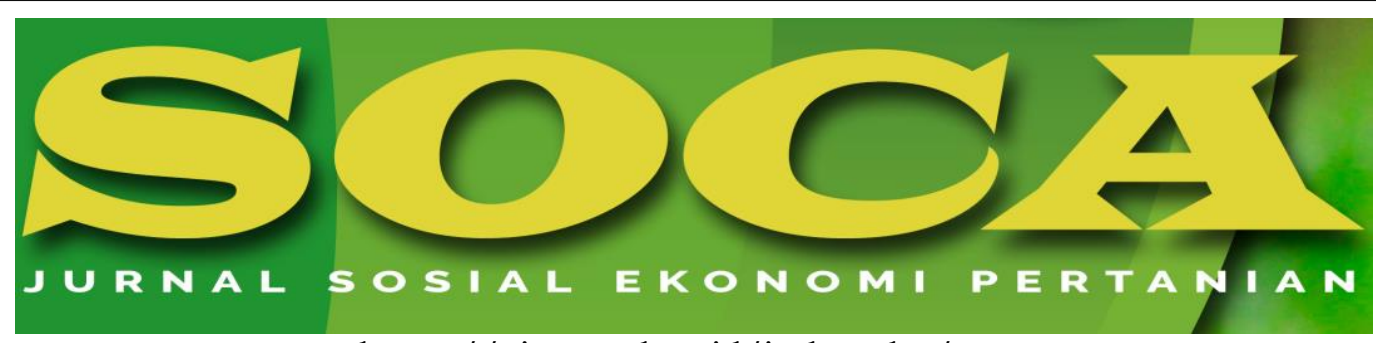

https://ojs.unud.ac.id/index.php/soca

\title{
The Economic Efficiency of Buffalo Business (Bubalus Bubalis) With the Shepherd
}

\author{
Supardi Rusdiana, Lisa Praharani and Riasari Gail Sianturi \\ Animal Research Center, PO Box 221, Ciawi-Bogor \\ E-mail: s.rusdiana20@gmail.com \\ Mobile: 081282010532
}

Submitted: 15 January 2020; Revised: 12 February 2020; Accepted: 27 February 2020

\begin{tabular}{l}
\hline Keywords: \\
economic \\
efficiency; \\
buffalo; \\
business; \\
shepherds \\
\hline
\end{tabular}

\begin{abstract}
Abstrak
Buffalo has a very big role to the family economy of stockbreeders. But until now, buffalo business in Banten Province is still small, and has not led to commercial business. The research was conducted in Cibarani Village, Cisata District, Pandeglang Regency, Banten in 2016. This study used interview and questionnaire filling methods to the 24 buffalo breeders. By accidental sampling, sampling of respondents was found in the cage, house, paddy field and fields. Primary data were obtained from stockbreeders and secondary data were obtained from the local institution. Primary and secondary data were analyzed descriptively, quantitatively, $t$-test analysis and economic analysis. The aim of this research was to determine the economic efficiency of buffalo business (bubalus bubalis) with the shepherds in stockbreeders. The results showed that, the factors that influenced the increased economic efficiency of buffalo business in breeders had a significant effect on $(P<0.05)$ to the breeders profits variable. The female buffalo business by breeding, breeders' profits was Rp.7.889.000 / year, with $R / C 1.02$ higher. The male buffalo business by fattened up, breeders' profits amounting to Rp.7.575.000 with $R / C$ of 1.05 lower. The buffalo business in breeders by shepherded, through male fattened up or breeding, was economically worth to try.
\end{abstract}

How to Cite (APA 6th Style):

Rusdiana, S., Praharani, L., \& Sianturi, R. G. (2020). The Economic Efficiency of Buffalo Business (Bubalus Bubalis) With the Shepherd. SOCA: Jurnal Sosial Ekonomi Pertanian, 14(2), 275-287.

https://doi.org/https://doi.org/10.24843/SOCA.2020.v14.i02.p08 


\section{INTRODUCTION}

Almost all buffalo breeders in Cibarani Village, Cisata Sub-district, Pandeglang Regency, Banten Province, scale the buffalo breeding between 2-5 buffalos / breeders. The breeding of buffalo by shepherding in unused land, agricultural land, fields, rice fields and empty land owned by farmers that have not been working on. Until now buffalo business in Banten Province is still just a few, and has not yet led to commercial business. Actually in Banten Province, it is considered to have a strong commitment to buffalo development business and is ready as a national nursery center. Although the small-scale of buffalos breeding buffalo breeders still working on it. In addition to be an annual income, when breeders need money, buffalo can be sold to meet the needs of the breeder life necessities. According to Syahyuti et al., (2007) breeders took advantage of buffalo business opportunities, in order to improve welfare and certainly lead to breeders' independence business (Syahyuti 2007; Budi and Aminah 2009; Nuryanti et al. 2011).

Through some improvements, the buffalo business in Banten Province was quite promising, seen from the socio-cultural aspects of the citizens who were very fanatical about buffalo (Hamdan et al. 2011; and Rusdiana et al. 2012). The buffalo breeding business need to be comprehensive and directed to the main business and can guarantee the business continuity of up and down (Sunartomo 2015). In this context the development of buffalo breeding business can be a business opportunity, in addition to balancing demand and supply factors. If seen from their business, breeders only breed buffalos as a savings and the main business was farming. Some breeders breed female buffalos for nursery and male buffalos for fattened up. Until now, the effort in breeders have not yet considered the breeders labor costs, because the buffalos that were breed, considered as their own, so that labor costs were not calculated. However, buffalos in Banten still can provide a fairly good contribution for breeders to increase their income (Rusdiana and Herdiawan 2017).

The buffalos in Indonesia, especially in Java, was mostly local buffalo by $40 \%$, while the remaining of $60 \%$ was mud buffaloes or swamp (Swamp buffalow) (Hafid and Musalim, 2016). Buffalos have a special ability to digest low quality food to survive, so the feed cost is not too much, depends on the breeders ability to provide food (Singh et al. 2013); (Sari et al., (2013); Hariyadi et al., 2013) and (Sari et al. 2015). Buffaloes were able to live in difficult areas, especially if only the very low quality food was available (Mufiidah et al., 2013; Putra et al., 2017). This means that mud buffalos have a pretty good feature, compared to cows. Buffalo business has a very big role to the economy of breeder family in Banten region. To encourage the development of buffalo breeding business, the role of Government and private institutions is needed. The support for facilitation, regulation and the establishment of nursery areas also the application of applicable technology innovations will increase buffalo business.

Banten Province is ready to develop buffalo business through breeding, fattening up by providing prospective brood stock, and superior males especially for the needs of natural mating. The local buffalo is one type of meat producer buffalos which is very adaptive to the environmental conditions in Indonesia. That buffaloes are often found in each region and buffalo features compared to other ruminants. According to Mayulu et al., (2018), buffalos or known as Bubalus bubalis Linn, was 
a buffalo that has a very strategic function in Asia, Europe and America. Buffalos can take an important role in the socio-cultural life in the community and especially the breeders (Tokita et al., 2015). Buffalos functioned as a complementary meat producer or beef substituted. According to Qomariah et al., (2006) and Sweers et al., (2014) buffalos were native livestock, and sources of germ plasma, need to be preserved and developed.

Buffalos can be developed as a location-specific business on swamp and other land agro-ecosystems. As the improvement of technology and business competition got tighter, so the buffalo business can be increased through government institutional support. To face the tight competition in non-livestock businesses in using genetic resources, land resources and labor, needs to be improved. The buffalos that were breed by breeders in Banten Province were able to make a positive contribution as a meat producer, the breeder economic value. According to Fadillah, (2017), the special preferences to buffalo and community traditions in Banten should be a social capital to face the era of the cattle market. The development of buffalos in Banten Province was quite significant, so that it can promise the development of buffalos. To be seen from the socio-cultural aspect, people's preference for buffalo showed a high probability for buffalo breeders. The public perception which was motivated by metaphysical and spirituality elements must be seen as cultural heritage which was the root for the local strengthening of Banten.

The dynamics of Banten citizens and local wisdom, it was possible to experience a transformation towards rational thinking, which can increase the plus value of breeders through buffalo business. Likewise, to be observed from the economic technology aspect, people's basic knowledge about buffalo can be used as a basic for intensifying buffalo business (Fadillah, 2017). Buffalos have a very important role for breeders, both as a meat provider, income and social status in the community (Rusdiana et al., 2014). Buffalos can give a positive impact, especially if it is associated with the presence of buffalo as a complement to traditional ceremonies (Isbandi et al., 2017). Based on the problems that mentioned above then buffalo business for breeders can be maintained, in accordance with the conditions of Banten, it is very suitable for the development of buffalo business. The price of buffalo can be influenced by age, male and female and buffalo body condition (Komarudin et al., 2018). According to Mufiidah et al., (2013) and Maluyu et al., (2016), to increase the scale of buffalo breeding in breeders through providing good quality food, productive female buffalo germ, superior males and good cage. The aim of this research was to discover the economic efficiency analysis of buffalo business (Bubalus Bubalis) with the shepherd system in breeders and the importance of this research to be carried out.

\section{RESEARCH METHODS}

\section{Research location}

The research was conducted in Cibarani Village, Cisata Sub-district, Pandeglang Regency, Banten in 2016, using the field survey method, questionnaire and direct interview at the research location. The research location was supported by plantation land, agriculture, paddy fields, fields and empty land that have not been working on by the owner, so that a lot of green food was grown to the sufficiency of buffalo feed. 
Another thing was buffalo business was supported by the Regional Government of Banten Province, because the community was doing farming and buffalo business.

\section{Data Analysis}

The determination of respondents was by (purposive random sampling), of 24 buffalo breeders. The samples of respondents found at home, in the cage, in the rice fields and farms and in other places. Primary data were obtained from breeders which included the number of buffaloes that were kept, the number of buffalos that were sold, the price of buffalos of various ages, male and female. Secondary data were obtained from various field researches and from (Department of Agriculture and Animal Husbandry of Pandeglang Regency, Banten, 2018). The needs of breeder comprehension in a good buffalo business through counseling, research and government support. Then the primary data and secondary data were analyzed descriptively, quantitatively, t-test analysis and economic analysis. To discovered the economic value of buffalo business in breeders by breeding and fattening using $\mathrm{R} /$ $\mathrm{C}$ analysis (Rusdiana et al., 2012). The aim was to see whether buffalo business makes profit or loss. If the value of $\mathrm{R} / \mathrm{C}>1$, then the business was said to, if the value of $\mathrm{R} / \mathrm{C} 1<$ business had a loss and if the value of $\mathrm{R} / \mathrm{C}=1$, then the business does not experience profit or loss.

Whether the business will be continued or not depends on the business management. To discover the influence of several factors on buffalo business in breeders, analyzed using multiple linear regression t-test. The germs costs (X1), feed costs (X2), breeder labor costs (X3), medicine costs (X4) and costs for making cages and equipment (X5) as variables. The determining factor on the amount of influence between the independent variable $(\mathrm{X})$ and the dependent variable $(\mathrm{Y})$ was used to determine the value of the regression coefficient. The variables that can determine the selling price of buffalos can be seen from the age of buffalos, male, female, appearance, market price and selling price in breeders.

\section{RESULTS AND DISCUSSION}

\section{General Conditions of the Research Area}

Pandeglang Regency has an area of about $274,689.91$ ha or around $274.69 \mathrm{Km} 2$ and based on the work administrative area was divided into 35 sub-districts, 322 villages and 13 village offices. Pandeglang Regency topography consisted of low and high land with elevation variations between $0-1,778 \mathrm{~m}$ (masl) with an area of $85.07 \%$ of the total Regency area. The height difference in Pandeglang Regency was quite sharp, with the highest point around $1,778 \mathrm{~m}$ (masl). In mountainous areas had a height of $\pm 400 \mathrm{~m}$ above sea level, non-coastal lowlands had an average height of about $30 \mathrm{~m}$ above sea level and coastal lowland areas with an average height of around $3 \mathrm{~m}$ above sea level, the land slope in Pandeglang Regency were varies between 0-1\%; with an allocation of $0-15 \%$ of the plain area around the South Coast and the Selat Sunda coast; $15-25 \%$ hill area locations spread around; and allocation of $25-45 \%$ of the mountainous area in the Central and North sections (Department of Agriculture and Animal Husbandry of Pandeglang Regency, Banten, 2018). 


\section{The Description of Buffalo Breeders}

The population in the Pandeglang Regency Banten was 33,250 and spreaded in 28 Districts. For buffalo development, it was supported by the provision of IB service posts, which were spread in 28 sub-districts, to support self-sufficiency in buffalo meat 2018-2026. An increase in buffalo growth was supported by grass in the fields and farms. The buffalos were the superior products in Banten Province in fact the buffalo breeders were able to supply meat consumption needs as well as religious ceremony, especially for sacrifices. The buffalo breeders can supply to some areas in the provinces of West Java, DKI Jakarta and Tangerang (Mansyur, 2018). The economic performers, especially buffalo sellers, can take the advantage of buffalo market opportunities, when approaching the religious holidays. In Pandeglang Banten, most people are still breeding buffalos, especially in Cibarani Village, Cisata Sub-district, so the Pandeglang Regency Government planned to make it become The Buffalo Village. Fathony and Winarno (2014) Secretary of the Animal Husbandry and Animal Health Service Department (Distanakeswan) of Pandeglang Regency Cibarani Village will be designated as the Buffalo Village.

The design of the buffalo village was carried out as an effort to accelerate the buffalo population to increase and the economic value of breeders got higher. To be designed as the buffalo village, according to Fathony and Winarno (2014), it has been done since 2009. The design cannot be determined yet, because it required quite a long time. According to the Head of the Animal Husbandry Department of Lebak Regency, Iman Santoso (2018) in the future Banten Province will be the buffalo producer and can meet the demands of the external and internal markets (Mansyur, 2018). The increasing of buffalo population was expected to be able to push the economy of the Banten citizens to be increasing. Banten was able of food selfsufficiency if buffalo meat and breeders' economic benefits were increasing. The interview result with local Animal Husbandry Department officers can be concluded that, the variety of buffalo sellers is a collector; that was sellers who diligently visited one place to another to buy buffalo. The buffaloes that sold by breeders were usually buffalos which were no longer in production age and young male buffaloes between 10-12 months.

The breeders breed young male buffalos to be fattened up, which then buffalo males were sold at the suitable prices depend on buffalo conditions. Almost all of buffalo breeders had experience in their business, on average 19-25 years. So the buffalo business both by breeding and fattened up, breeders were used to it. In the breeding of buffalo by fattening up and germs, breeders can already assume the production costs and profits. Some of strategic ways taken in the development of buffalo business, to get a profit on buffalo sellers was by improving breeding. This collector seller was the first hand, because it was directly met the breeders / sellers. The collector sellers as the first chain that was directly met the breeders and their offered price this is called the farm gate price which was certainly lower than the price at the end consumer level.

\section{The Price of Buffalos in Breeders}

Buffalos are one of the large livestock with high economic value, (Bubalus bubalis). Buffalo was quite well known in Banten society, and in general already knew it, as one proof of the importance of buffalo in the culture of Banten community and other 
communities in Indonesia. Buffalos can be categorized from various types of buffalos and generally can be seen from the body size, shape, horns, and the combination of the skin color was quite diverse. The shape of the buffalo horn determined the sale value, but the role of the horn for the male buffalos was more important than the female buffalos. In female buffalos, usually the size and shape of the female buffalo horns were not mush considered. Usually the demand for buffalo meat on the market was quite high for the needs of Eid al-Adha and Eid al-Fitr. Until now, the livestock business in the Regency of Banten Province still considered the buffalo to be a complement business. So that, the local government continues to coach about buffalo business and also increasing in the population through the IB and selection of female germs and male superiors.

With the support of the Central and Regional Governments, confidently, buffalo breeding in Banten Province can increase the population and welfare of breeders and increase employment. The price of buffalo in the Banten region ranges from Rp. 2030 million / buffalo. In average, breeders breed mud buffalos. The buffalos weight between 400-600 kg. The buffalo breeding techniques were kept improving through breeders resources according to location. All buffalo breeders used green grass that grew around the residential neighborhoods and empty land. Besides agricultural waste, breeders also provided additional food, which are tofu pulp and provided vitamins in order to increase the buffalo growth. Thus, buffalo breeders still used grass as the main food source, so the buffalo population growth was quite slow. The necessity of institutional support that related to the success of buffalo business was expected to use supplementary food and vitamins to increase the productivity of buffalos.

The buffalo breeders in Banten Province exploited oil palm plantation area because there was green grass and has been approved by the owner or manager of the oil palm plantation. According to Fadillah, (2017), the culture and social system value, so the first step to the development of modern buffalo breeding must started from culture strengthening and innovation. Besides that, it must abandoned the driven factor, which was the effort to reduce dependence on the nature giving required a change in mindset, from self-sufficiency to market oriented. Simply, it can be said that the techno-cultural mutation should rely on the spirit of transformation from the breeder culture to the independent breeder in accordance with the local wisdom of the Banten community. According to Fadillah (2017), the potential of buffalo in Banten was still quite promising in the mid of the improvement of large ruminant biotechnology. History, traditions, preferences and buffalo trade were continuing to run as a business, in almost all regions of Banten.

When meat consumers increase while buffalo availability was unable to supply, meat importation was always be the solution. It was expected that with the increase of small breeders breed buffalo, it will be able to substitute meat, so that meat imports did not occurred (Sari et al., 2015). The less amount of buffalos breed by a breeder, but with the high number of breeders breed, buffalos will increase and technically the buffalo population will increase. Technically, it seemed easy to breed buffalos in a modern way, if the problem focused on two things (Sari et al., 2016). First, biological factors such as the nature characteristics of buffalo that made buffalo breeding not as easy as cow. Secondly were the technological factors such as the 
limitations of superior germs, food quality, cross-breeding, breeders' lack of knowledge in biotechnology and agribusiness.

\section{The Production Cost of Buffalo Business}

Breeders got profit from the sale of young male females of various ages and old buffalos which were no longer productive. For the mother buffalo that was breed to produce young buffalos, actually still has an estimated time of about 5-7 years and 4 times childbirth (Kusnadi 2011). Most of the $70 \%$ buffalos breeding system were still managed by small breeders in rural areas with limited mastery of land resources, income, innovation and technology. This situation showed that buffalo business has not been much directed to commercial business, which was a complement business that was characterized by relatively small business scale and improper breeding management (Sari et al., 2015). Breeders got profit, if they sold buffaloes directly and receive money, so it was considered a big profit. In fact, according to the economy, buffalo sales cannot be said to be profitable, because there were still costs incurred during the business and have not been calculated by breeders. However, breeders never calculate the production cost or labor costs, because buffalos were considered their own property. This did not make a complicated problem for breeders, so the buffalo business was still well-managed.

The economic calculation for buffalo business, investment costs for land, building cages, buffalo, and land. The biggest investment cost that was mostly spent by breeders was the business capital to buy buffalo as the first germ. Then the variable costs tend to always change every year, according to the number of buffalos that were breed. The increasing volume of buffalo production, will affect the additional costs for raw materials, labor and others. The permanent costs that always incurred by breeders in general were always constant. Where the business expenses did not depend on the need to purchase goods or services which produced by breeders. These expenses were related to time, such as labor costs, feed costs, land costs and other unexpected costs. Variable costs are costs that generally changed according to the number of buffalo that being breed. The breeders' income will be even greater if there were enhancement in the production volume of buffalo and buffalo sales.

Then the increasing cost will have to be incurred for buffalo production. The balance between the growth of buffalo production and sales will increase buffalo selling value. The income was all the results received by farmers from the sale of buffalo for one year as output. The cost breakdown in the buffalo business can be seen from several business variables. Making cage cost, the cost of a cage was at 1 unit on the average Rp.3.750.000 / unit. The cost of cage equipment was Rp. 300,000 / package / year. The depreciation costs for a cage for 5 years were Rp. 750,000 / year. Depreciation cost of cage equipment / year was Rp. 25,000/year. The amount of depreciation expense was Rp.775.000 / year.

\section{Economic Value, the Business Costs of Female Buffalo}

The cost of purchasing female buffalo germs as mothers candidate and three mothers with an average age of 2.4-3.5 years, with an average price of Rp. Rp.9,640,000/buffalo, or as much as Rp. 28,920,000, - The cost of making a cage at 1 unit on average was Rp.3,750,000 / unit. The cost of cage equipment was Rp. 300,000 / package / year. Depreciation costs for a cage for 5 years were Rp. 750,000 
/ year. Mother depreciation expense of 2.5\% / year amounting to Rp.723,000 / year. Depreciation cost of cage equipment / year was Rp. 25,000 per year. The total amount of depreciation expense was Rp.1,498,000 / year.

The cost of purchasing medicines was Rp. 100,000 / package / year. Labor costs for buffalo breeders, 1 person x 15,000 / day x year Rp.5,475,000 / year. The cost of purchasing forage was $20 \mathrm{~kg}$ x 3 buffalos $\mathrm{x}$ the price of Rp.200 x a year was Rp.4,380,000 / year. Total production costs were Rp.46,013,000- / year. The total amount of depreciation and production costs was Rp.7,511,000.

\section{Income}

The sale of mother buffalos which no longer productive or reject, 1 buffalo of Rp. $8,150,000$ / buffalo. The income of the sale of young male buffaloes and 2 female buffalos with an average age of 5-6 months, with a price of Rp.7.25,000/buffalo. Total gross income of Rp.15,400,000 / year. Total net income of Rp. 7,889,000 / year with an $\mathrm{R} / \mathrm{C}$ of 1.05

\section{The Economic Value, the Business Cost of Male Buffalo}

The cost of purchasing 3 male buffalo germs for fattened up with an average initial age for breeding around 1.2 years, an average price of Rp.10,250,000/buffalo or as much as Rp.30,750,000 / year. The cost of purchasing medicines was Rp. $100,000 /$ package/year. The labor cost for buffalo breeders was 1 person x 15,000 / day x year of Rp.5,475,000 / year. The cost of purchasing forage was $20 \mathrm{~kg}$ x 3 animals $\mathrm{x}$ the price of Rp.200 x a year was Rp.4,380,000/ year. The total production cost was Rp. 40,705,000/ year. The total amount of depreciation and production costs was Rp. 41,475,000.

\section{Income}

The sale of 3 male buffalos as the results of fattened up for 1 year with average price of Rp. 16,350,000/buffalo or as much as Rp. 49,000,000 / year, total gross income of Rp. 49,000,000 / year, total net income of Rp. 7,575,000 / year with R / C of 1.02. The income analysis of germs buffalo and fattened up buffalo was shown in Table. 1

Table.1. The Analysis of business income of fattened up and germs buffalos in breeders

\begin{tabular}{lll}
\hline Description & $\begin{array}{l}\text { Female buffalo } \\
\text { (Amount/Rp) }\end{array}$ & $\begin{array}{l}\text { Male Buffalo } \\
\text { (Amount/Rp) }\end{array}$ \\
\hline Depreciation and production cost & 7.511 .000$, & 41.475 .000 \\
Gross income/year & 15.400 .000 & 49.000 .000 \\
Net income/year & 7.889 .000 & 7.575 .000 \\
R/C & 1,05 & 1,02 \\
\hline
\end{tabular}

Source: Research Result Data (processed, 2019)

Table 1, showed that, female buffalo business by germs, breeders profits of Rp. $7,889,000$ / year with an R / C value of 1.02 higher. Male buffalo business by fattened up, the profits of breeders amounting to Rp.7,575,000, - with an R / C value of 1.05 lower. Low profits for breeders in buffalo businesses, labor production costs and more feed. Another thing was caused by the long cycle of buffalo production (birth spacing), which was considered inefficient for small-scale businesses. Female 
buffalo can shorten the distance to give birth, so the buffalo business was more efficient. The breeding business of 2 male buffaloes by fattened up, the profits of breeders amounting to Rp. 3,700,000 / buffalo, R / C ratio of 1.06 (Rusdiana and Praharani 2015a). Buffalo business by breeding, breeder profits was of Rp. 2,800,000 / buffalo, with R / C of 1.04 Rusdiana and Praharani (2015b). The results of research on breeding business of 2 main female buffaloes and 1 adult male buffalo profit of Rp. 4,500,000 / year with an R / C of 1.15 (Rusdiana et al., 2012). The results of Kusnadi's research (2011) showed that the breeding of 5 buffalos in Banten in the breeder's net profit was Rp. 4,128,000 / year with an R / C of 1,12. The buffalo business in breeders, both breeding by fattened up and germs was economically worth to try.

\section{Factors that Influence Buffalo Business in Breeders}

The production costs in the buffalo business can be offset by the selling price of buffalo. Buffalo business conditions in breeders can provide optimal benefits, if the production costs were lower than profit. The factors that influence the profits of buffalo breeders came from each variable, (Y). The connection on buffalo business variables were for germs purchasing costs (X1), feed purchase costs ((X2), labor costs (X3), medicines costs (X4) and cage and equipment costs (X5). Breeders' profits for costs production incurred for one year on male and female buffalo businesses. The cost of buying buffalo germs was the largest production cost, because it was the main asset as a business investment. This proved that at the scale of male buffalo business to be fattened up and female buffaloes for breeding germs simultaneously on variables purchase of germs, feed, medicine, labor and land rent. Production costs made a significant influence on the profits of buffalo breeding. The factors that affected the buffalo business in breeders were shown in Table 2.

Table.2. The Factors that Influence Buffalo Business

\begin{tabular}{|c|c|c|c|}
\hline Variable & $\begin{array}{l}\text { Regression } \\
\text { Coefficient }\end{array}$ & t.count & $\begin{array}{c}\text { Prob.Significa } \\
\text { nce }\end{array}$ \\
\hline Cost of buying germs $\left(\mathrm{X}_{1}\right)$ & 0,4713 & $-0,3324$ & $0, .0000 * *$ \\
\hline Cost of buying food (( $\left.\mathrm{X}_{2}\right)$ & 0,6552 & $-0,4745$ & $0,127^{* * *}$ \\
\hline Cost of labor $\left(\mathrm{X}_{3}\right)$ & 0,7612 & $-0,1726$ & $0,131^{*}$ \\
\hline Cost of medicines $\left(\mathrm{X}_{4}\right)$ & 0,3115 & 0,54347 & $0,000^{* * *}$ \\
\hline Cost of cage and equipment $\left(\mathrm{X}_{5}\right)$ & $-0,6547$ & $-0,6323$ & $0,3476^{* *}$ \\
\hline R-squared & 0,73455 & & \\
\hline Adjusted R- square & 0,46956 & & \\
\hline Prob-Sig & 0,0000 & & \\
\hline
\end{tabular}

Table 2 showed that, the buying of feed variable ((X2) significantly influences (P $<0.05)$ the buffalo breeder profit variable, then the costs that affected buffalo business (X3) on labor according to Rusdiana et al., (2014), the labor costs of buffalo 
breeders were based on the amount of costs incurred for one year. Usually, the breeders rarely calculated labor costs, because they were considered buffalo selfowned, the cost of purchasing male and female germs was 0.065, the cost of purchasing feed was 0.6552, Labor costs were 0.7612, medicine costs were 0.3115, and the cost of making cages and cage equipment (X5) was -0.6547 . The cost of buying buffalo germs for males and females (X1) was -0.4713 . The cost of purchasing feed (X2) 0,6552, the cost of purchasing medicines (X4) 0,3115, the cost of making an unit cage and cage equipment (X5) -0,6547. The calculation results showed a value of 5.261 with a Sig value of 0,000 .

The production factors by multiple linear regression analysis with the equation: $Y=(-0.065)+.(0.4713 X 1)+(-0.655 X 2)+(0.7612 . X 3)+(0.3115 X 4)+-(0.654 X 5)$. Male buffalo business by fattened up and female buffalo by breeding breeders' profits can be offset by buffalo selling prices. The profit of buffalo breeders was influenced by several factors or costs as a variable for one year. If income was lower it was likely due to higher production costs, and lower buffalo selling. The breeders considered profit if, the breeders received the money in cash or directly from the sale of buffalo.

\section{CONCLUSION}

Based on the results of the research, it can be concluded that, Banten Province has good potential for buffalo business development. To be discovered from the support of vacant land, plantations, agriculture and breeder resources and socio-cultural culture of the Banten people who were fanatic about buffalo. Female buffalo business by breeding the breeders' profits was Rp.7.889.000/year, with an R / C value of 1.02 higher. The business of male buffalo by fattened up the profits of breeders amounting to Rp.7.575.000, - with an R / C value of 1.05 lower. The buffalo business in breeders, both breeding by fattened up and germs breeding were economically worth to try. Factors that influenced the improvement of buffalo business economic efficiency in breeders have a significant effect on $(\mathrm{P}<0.05)$ on the profit variables of breeders.

\section{RECOMMENDATION}

The increasing or expanding scale of breeders' businesses was through increasing the asset of buffalo germ purchases and providing good quality feed. Guaranteed buffalo prices in breeders and the need for institutional support related to the success of buffalo business. Buffalo business, if it was endeavored in a process and was a commodity that was maintained in an integrated manner with agricultural business, the profits of breeders will be optimal. It was recommended to develop buffalo business in an integrated manner and supported by efficient management of trained, effective human resource breeders, so that it will increase the scale of business and increase the breeder's economic value. It was expected that breeders can increase the scale of buffalo business from a scale of 2-3 buffalos / breeders to 4-7 buffalos / breeders, the profits of breeders will be obtained from the results of children and indirectly the breeder's economy will increase. 


\section{REFERENCES}

Budi, G.S. dan M. Aminah. 2009. Faktor-faktor dominan dalam pembentukan lembaga sosial. Jurnal, Forum Penelitian Agro Ekonomi. Pusat Analisis Sosial Ekonomi dan Kebijakan Pertanian. Juli 2009, 27(1):51-58.

Fathony dan Winarno. 2014. Desa Cibarani Akan Dijadikan Sebagai Kampung Kerbau, [Internet] [Diakses tgl, 26 desember 2019]. Tersedia dari http:/ / www.detakbanten.com/today/4183-desa-cibarani-akan-dijadikansebagai-kampung-kerbau, diakses tgl, 26 Desember 2019.

Fadillah Moh. Ali. 2017. Kerbau Dalam Tradisi Banten (Edisi 3-7) [Internet] [Diakses tgl, 26 desember 2019]. Tersedia dari https://tuntasmedia.com/2017/09/05/kerbau-dalam-tradisi-banten-edisi-37/akses tgl, 26 Desember 2019.

Hamdan, A., E.S.Rohaeni,A.Subhan dan R.Qomariah. 2011. Strategi pengembangan ternak kerbau rawa di Kalimantan Selatan. Seminar dan Lokakarya Nasional KerbauPuslitbangnak Bogor, Lebak 3-4 Agustus 2010, hal.15-121.

Hariyadi, W.O., Suwandyastuti S.N.O, Bata. M. 2013. Peningkatan Kualitas Pakan Kerbau Ditinjau dari Kecernaan Bahan Kering dan Kecernaan Bahan Organik. Jurnal Ilmiah Peternakan, 1(3):768-773.

Hafid Nur dan Mursalim. 2016. Analisa usaha peternakan kerbau lokal (bubalus bubalis) dengan sistim gembala di desa dingil kecamatan jatirogo kabupaten tuban Jurnal Fillia Cendekia 1(2):18-14 http:/ / fp.uniska-kediri.ac.id/ejournal

Hafid. N, Mursalim. 2016. Analisa peternakan Kerbau lokal (Bubalus bubalis) dengan system gembala di Desa Dingil Kecamatan Jatirogo Kabupaten Tuban. Jurnal Fillia Cendekia 1(2):8-14.

Isbandi, Soeharsono dan S. Rusdiana. 2017. Marjin Pemasaran Ternak Kerbau di Pasar Hewan Bolu Kabupaten Toraja Utara (Margin of Buffalo Marketing at the Bolu Animal Market, North Toraja District) Bogor, 10-12 Nopember 2017. 177182

Kusnadi, U. 2011. Nilai ekonomi tataniaga kerbau dari Kabupaten Pandeglang dan Kabupaten Lebak Propinsi Banten. Prosiding Seminar Nasional Teknologi Peternakan dan Vetriner, Puslitangnak Bogor, 7-8 Juni 2011, hal, 209-217.

Komarudin, Burhanuddin dan N.Prmatasari. Analisis potensi dan pengembangan kerbau lumpur di Kabupaten Serang. Jurnal Ilmu-Ilmu Peternakan dan teknologi Hasil Peternakan 6(3):90-97.

Nuryanti, S., dan Swastika, DKS. 2011. Peran kelompok tani dalam penerapan teknologi pertanian. Jurnal, Forum Penelitian Agro Ekonomi, 29 (2):115-128

Mayulu Hamdi, N. Maulida, R. Yusuf, S. N. Rahmatullah. 2018. Pengaruh biaya produksi terhadap pendapatanusaha peternakan kerbau rawa (bubalus bubalis linn) di Kabupaten Hulu Sungai Utara Provinsi Kalimantan Selatan Jurnal Teknologi Pertanian Universitas Mulawarman 13(2):58-64 
Mufiidah N, Ihsan M.N, Nugroho H. 2013. Produktivitas Induk Kerbau Rawa (Bubalus bubalis) Ditinjau Aspek Kinerja Reproduksi dan Ukuran Tubuh di Kecamatan Tempursari Kabupaten Lumajang. J. Ternak Tropika 14(1):21-28.

Mansyur. 2018. Populasi Kerbau Di Lebak Bertambah, Pewarta, Editor : Ganet Dirgantara, Copyright, Antara, [Internet] [Diakses tgl, 26 desember 2019]. Tersedia dari https://banten.antaranews.com/berita/29477/populasikerbau-di-lebak-bertambah, di akses tgl, 26 Desember 2019.

Maluyu Hamdi, N.Maulida, R.Yusuf dan S.N.Rahmatullah. 2018. Pengaruh biaya produksi terhadap pendapatan usaha kerbau rawa (Bubalus bubalis Lin) di Kabupaten Hulu Sungai Utara Propinsi Kalimantan Selatan. Jurnal Teknologi Pertanian, Universitas Mulawarman 13(2):58-64

Putra DE, Sarbaini, Afriani T. 2017. Estimasi potensi ternak Kerbau di Kecamatan Ulakan Tapakis Kabupaten Padang Pariaman Provinsi Sumatera Barat, Indonesia. Jurnal Veteriner 18(4): 624-633.

Qomariah, Kartiarso, Lita M. 2014. Produktivitas Kerbau Rawa Di Kecamatan Muara Muntai, Kabupaten Kutai Kartanegara, Kalimantan Timur. Buletin Peternakan 38 (3): 174-181.

Rusdiana, S., I.G.A.P. Mahendri dan C. Talib. 2012. Pendapatan usaha ternak kerbau di Kecamatan Gunung Sindur Kabupaten Bogor. Prosiding Seminar dan Lokakarya Nasional Kerbau Puslitbangnak Bogor, Samarinda 21-22 Juni 2012. h1.152-158.

Rusdiana, IGM. Budiharsana S. Sumanto, 2014. Analisis pendapatan usaha pertanian dan peternakan kerbau di Kombok, Nusa Tenggara Barat. Jurnal of Agriculture, Resaurce and Enviromental Economics. Jare IPB, 2(2):56-67.

Rusdiana, S., dan L. Praharani. 2015a. Estimated value of live buffalo frice in the economic analysis of the income farmers in the village. Proseeding International seminar on anilam indutry, Faculty of Animal Science Bogor Agricultura University IPB, September 17-18-2018, hal.388-293.

Rusdiana, S. dan L, Praharani. 2015b. Economic analysis and the impact of IA tehnology on buffalo to the farmers income. Proceeding International Seminar on Tropical Productiona The 6th. Istap, Universuty Gajah Mada, Oktober 2022-2015, hal. 582-585

Rusdiana, S. dan Iwan Herdiawan. 2017. Pengetahuan peternak dan analisis ekonomi penggunaan rumput chloris gayana sebagai pakan kerbau di lahan penggembalaan. Buletin Peternakan UGM, 41(2):219-229.

Syahyuti. 2007. Kebijakan pengembangan gabungan kelompok tani (gapoktan) sebagai kelembagaan ekonomi di perdesaan. Jurnal Analisis Kebijakan Pertanian Maret 2007, 4(8):66-72

Sari Eka. Meutia, H. Basri dan Safrizal., 2012. Tatalaksana pemeliharaan kerbau ditinjau dari aspek teknis pemeliharaan di kabupaten Gayo Lues. Agripet.Juli 2012, 12(2):33-36. 
Singh, M, Chaudhari B.K, Singh J.K, Singh A.K, and Maurya. P.K. 2013. Effects of thermal loadon buffalo reproductive performance during summer season. Jouttal Bio Sci, Juni 2013, 1(1):1-8

Sweers W, Mohring T, Muller J. 2014. The economic buffalo (Bubalus bubalis) breeding, rearing and direct marketing. Archiv Tierzucht 57(2):1-11.

Sunartomo. A.F. 2015. Perkembangan konversi lahan pertanian di Kabupaten Jember. Agroekonomika Trunojoyo. Jurnal Penelitian Sosial Ekonomi dan Kebijakan Pertanian April 2015,.4(1):22-36

Sari Eka Meutia, Mohd, Agus Nashri Abd dan Sulaiman. 2015. Kajian Aspek Teknis Pemeliharaan Kerbau Lokal Di Kabupaten Gayo Lues,Fakultas Pertanian, Jurusan Peternakan, Universitas Syiah Kuala, Darussalam- Banda Aceh. Agripet Mei 2015, 15(1):57-60

Sari Eka Meutia, Mohd. Agus Nushri A dan Sulaimen. 2016. Kajian aspek teknis pemeliharaan kerbau lokal di Kabupaten Gayo Lues. Jurnal Agripet 15(1):5760

Tokita N, Shirasaka A, Thiangtum W, Ratanapob N, Kawamoto Y, Tokita T.2015. Potential digestibility of tropical grasses for swamp buffalo (Bubalus bubalis) in Thailand. Asian Journal of Pland Science and Research 5(11):32-37. 